\title{
Jefferson fractures
}

\author{
Sibhi Ganapathy ${ }^{1, *}$, Swaroop Gopal ${ }^{2}$, T. V. Ramakrishna ${ }^{3}$ \\ ${ }^{1}$ Consultant, ${ }^{2}$ Director and Senior Consultant, ${ }^{3}$ Associate Consultant, Dept. of Neurosciences, ${ }^{1}$ Manipal Hospital, Whitefield, \\ Bengaluru, Karnataka, ${ }^{2,3}$ Institute of Neurosciences, Sakra World Hospital, Bangalore, Karnataka, India
}

*Corresponding Author:

Email: sibhig@yahoo.co.uk

\section{Introduction}

Jefferson fractures are rare and classically describe the 4 part fracture of the atlas.

They make up approximately $7 \%$ of cervical spine fractures, but are closely associated with $\mathrm{C} 2$ fractures (almost 50\%). As the risk of neurological injury is low, (around 4-17\%), these fractures are commonly missed in emergency rooms. ${ }^{1}$

Although originally decribed by Sir Goeffrey Jefferson in London in 1924, the term has become an eponym for all fractures of the Atlas.
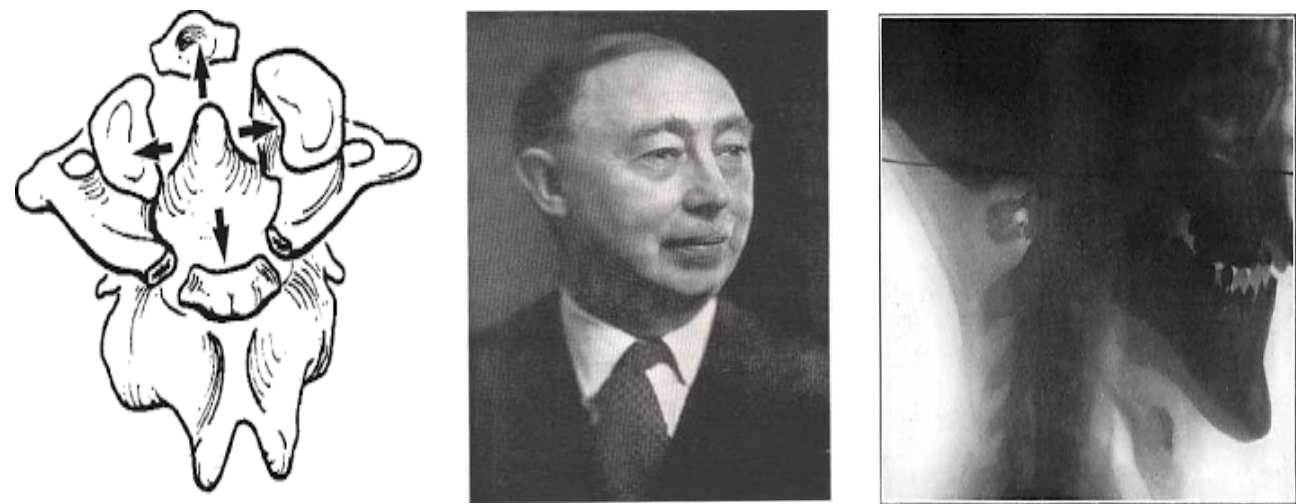

Fig. 1: Represents the original article along with a picture of Sir Goefrey Jefferson

Fig. 1 represent the Jefferson's original article published in 1920. He proposed that due to the wedge shape of the lateral masses, a compressive loading stress was converted into a decompressive force leading to the fracture in question. ${ }^{2}$

\section{Biomechanics}

In response to trauma, the Craniovertebral junction $(\mathrm{CVJ})$ exhibits predictable patterns of failure based on the mechanism of injury. The $\mathrm{C} 1$ acts as a washer between the occipital condoyles and the $\mathrm{C} 2$ beffering the force transmitted down. Thus the $\mathrm{C} 1$ is extremely vulnerable to axial forces which while pressing down cause the burst fracture medial to the lateral masses.

The lateral mass on $\mathrm{C} 1$, being taller, is directed laterally. Therefore vertical forces compressing the lateral masses between the occipital condyles and the axis drive them apart, fracturing one or both of the anterior or posterior arches. The impact forces cause an outward spread of the lateral masses of $\mathrm{C} 1 .^{3}$

A Jefferson fracture doesn't always result in a spinal cord injury, as the dimensions of the bony ring increase, leading to spinal canal auto-decompression.
Spinal cord injury is more expected if the transverse atlantal ligament (TAL) is ruptured due to atlanto-axial instability. An ADI $>3 \mathrm{~mm}$ indicates Atlanto-Axial dissociation (AAD) while an Atlanto-Ddental Interval (ADI) of $>5 \mathrm{~mm}$ indicates alar ligament and Transverse Atlantal Ligament (TAL) damage. ${ }^{3}$

In animal models, fracture patterns have been reproduced in axial compressive forces and distractive shear stresses on the lateral masses. ${ }^{4,5}$

Ligamentous injury is usually rare in classic Jefferson fractures, but when present is usually occurs as an osteoperiosteal avulsion of the transverse ligament or a complete avulsion of the tubercle of the atlas. This leads to displacement of the lateral masses which can be picted up on radiology. It can be diagnosed by identifying bony spur avulsion on CT, by TAL rupture on MRI as well as by detecting the widening of the lateral masses on an CV junction Xray (open mouth AP view). ${ }^{6}$

The various types of injuries have been summarised below: 
Table 1: Description of the mechanism of injury along with resultant fracture types and ligamentous injury

\begin{tabular}{|c|c|c|}
\hline $\begin{array}{l}\text { TYPE OF } \\
\text { INJURY }\end{array}$ & BIOMECHANICS & LIGAMENT INJURY \\
\hline $\begin{array}{l}\text { CLASSIC } \\
\text { Jefferson } \\
\text { fracture }\end{array}$ & Axial loading & \\
\hline $\begin{array}{l}\text { Lateral } \\
\text { mass } \\
\text { fracture }\end{array}$ & $\begin{array}{l}\text { Axial loading with } \\
\text { supraphysiological } \\
\text { rotation }\end{array}$ & \\
\hline $\begin{array}{l}\text { Anterior } \\
\text { arch } \\
\text { fracture }\end{array}$ & $\begin{array}{l}\text { Pathologocal } \\
\text { flexion. } \\
\text { Associated with } \\
\text { complex injuries of } \\
\text { the CVJ }\end{array}$ & $\begin{array}{l}\text { Crutiate ligament damage (all or none phenomenon) } \\
\text { Tectorial membrane rupture } \\
\text { Dural tears if severe }\end{array}$ \\
\hline $\begin{array}{l}\text { Posterior } \\
\text { arch } \\
\text { fracture }\end{array}$ & $\begin{array}{l}\text { Hyperextension } \\
\text { Rarest of injuries }\end{array}$ & $\begin{array}{l}\text { Alar ligament, } \\
\text { Tectorial membrane, } \\
\text { Crutiate ligament, accessory atlantoaxial ligaments } \\
\text { exposed to severe shearing stress }\end{array}$ \\
\hline
\end{tabular}

\section{Classification}

Jefferson fractures have been classified depending upon the site of fracture as well as by the presence or absence of CV junction instability. Landel's Classification is the current classification in vogue. It is compared below, with the original classification proposed by Jefferson.

Table 2: Description of the classification systems for Jefferson fractures

\begin{tabular}{|l|l|l|l|l|}
\hline $\begin{array}{c}\text { Jefferson } \\
\text { Type }\end{array}$ & $\begin{array}{c}\text { Lendell } \\
\text { Type }\end{array}$ & \multicolumn{1}{|c|}{ Description } & Stability & \multicolumn{1}{|c|}{ Treatment } \\
\hline $\begin{array}{l}\text { Type 1 \& } \\
\text { Type 2 }\end{array}$ & Type 1 & $\begin{array}{l}\text { Isolated anterior or posterior arch } \\
\text { fracture. }\end{array}$ & Stable & $\begin{array}{l}\text { Collar if the transverse atlantal } \\
\text { ligament (TAL) is intact. }\end{array}$ \\
\hline Type 3 & Type 2 & $\begin{array}{l}\text { Jefferson burst fracture with bilateral } \\
\text { fractures of anterior and posterior arch } \\
\text { resulting from axial load. Stability } \\
\text { determined by integrity of transverse } \\
\text { ligament (TAL) }\end{array}$ & Variable & $\begin{array}{l}\text { If TAL intact then collar. If } \\
\text { disrupted then halo vest or } \\
\text { surgery. }\end{array}$ \\
\hline Type 4 & Type 3 & $\begin{array}{l}\text { Unilateral lateral mass fracture. } \\
\text { Stability determined by intefrity of } \\
\text { transverse ligament. }\end{array}$ & Variable & $\begin{array}{l}\text { If TAL intact then collar. If } \\
\text { disrupted then surgery. }\end{array}$ \\
\hline
\end{tabular}

\section{Clinical Features}

A high degree of clinical suspicion is required to detect these fractures as no neurological deficit occurs and pain due to the fracture is often attributed to soft tissue injury. Patients usually complain of upper neck pain alone. 


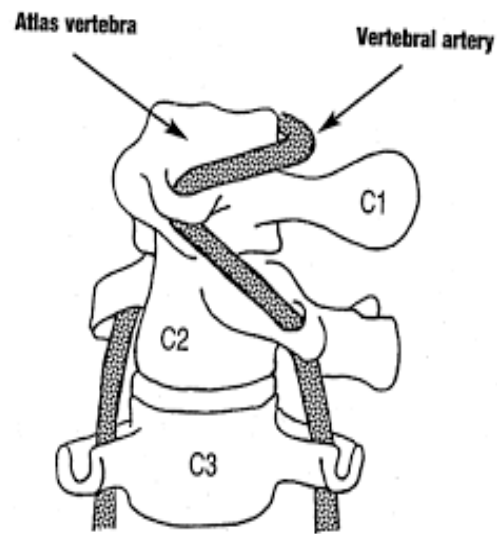

Fig. 2: Shows the anatomical course of the vertebral artery in the Cranio-Vertebral Junction

Fig. 2 Vertebral artery injuries are rare $(<2 \%)$ with classic Jefferson fractures. It mainly occurs in posterolateral fractures which pass through the vertebral groove. The vertebral groove is seen in the posterior aspect of the $\mathrm{C} 1$ and is flattened superolaterally, unlike the medial aspect of the posterior arch which is anteroposteriorlly flattenned. The junction of these two zones on the $\mathrm{C} 1$ arch is the commonest site for fracture. The vertebral grove is composed of thick cortical bone and is thus protected from injury making damage rare. ${ }^{7}$

The vertebral artery in the $\mathrm{C} 1$ region consists of the V3 segment of the vessel which is further divided into a
V3-Horizontal and a V3-Vertical. The horizontal segment lies within the groove while the vertical segment pierces the tentorial membrane and moves inside the dura into the foramen magnum to combine with the opposite vertebral artery to form the basilar artery and supply the brainstem. In 55\% of situations, only the left vertebral artery is dominant, while in only $15 \%$ are both codominant. The vertebral artery also gives rise to the anterior spinal artery before it enters the intradural course. Rarely the posterior spinal arteries, which are branches of the Posterior Inferior Cerebellar Arteries (PICAs) can also arise from this region. ${ }^{7}$

Thus the vertebral artery on the suboccipital triangle (formed by the obliqus capitus superior, Oblicus capitus inferior and the Rectus capitus posterior major) along the $\mathrm{C} 1$ vertebral groove is of consumate importance and must be preserved at all costs.

C2 nerve root pain may occur rarely during the recovery phase primarily due to scarring on the nerve root during immobilization. Rarely the $\mathrm{C} 2$ root may also be sacrificed during surgery when the $\mathrm{C} 1$ lateral mass is to be exposed. ${ }^{7}$

\section{Radiology}

Plain X-Rays are the easiest and simplest method for detecting fractures in the atlas. The best views to investigate the atlas include:
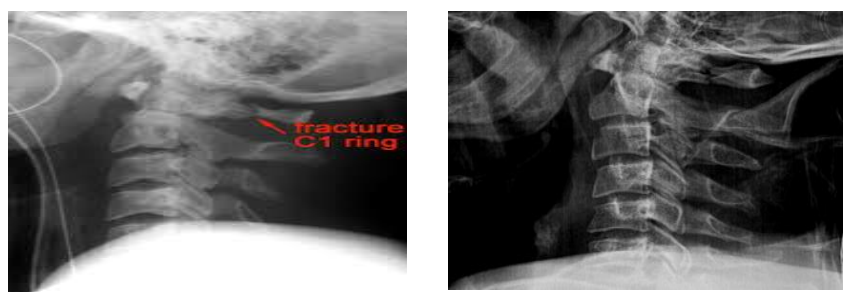

Fig. 3: Represents a lateral X-ray of the Cervical Spine and CVJ, showing a posterior Jefferson fracture along with increase in the pre-vertebral soft tissue density

The presence of atlanto-axial fractures can be detected on lateral radiographs. Posterior fractures are easier to detect.

The presence of retropharyngeal soft tissue density greater than $2 \mathrm{~mm}$ should increase the suspicion of the radiologist for $\mathrm{C} 1$ injury.
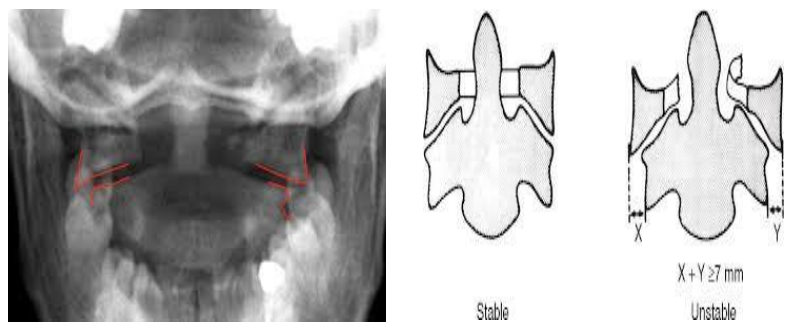

Fig. 4: Shows the Open Mouth X-Ray demonstrating the Rule of Spence

CT Scans: are the Gold Standard for diagnosing the Jefferson fractures. 2D reconstruction helps in diagnosing the displacement of the lateral masses. ${ }^{8}$ 
Open-mouth odontoid view is of critical importance to identify atlas fractures as well as to identify transverse ligament damage. Here, the sum of lateral mass displacement or overhang above the $\mathrm{C} 2$ body is used to detect transverse ligament damage. If the sum of lateral mass displacement is $>7 \mathrm{~mm}(8.1 \mathrm{~mm}$ with radiographic magnification) then a transverse ligament rupture is assured and the injury pattern is considered unstable. This is often refered to as the rule of Spence.
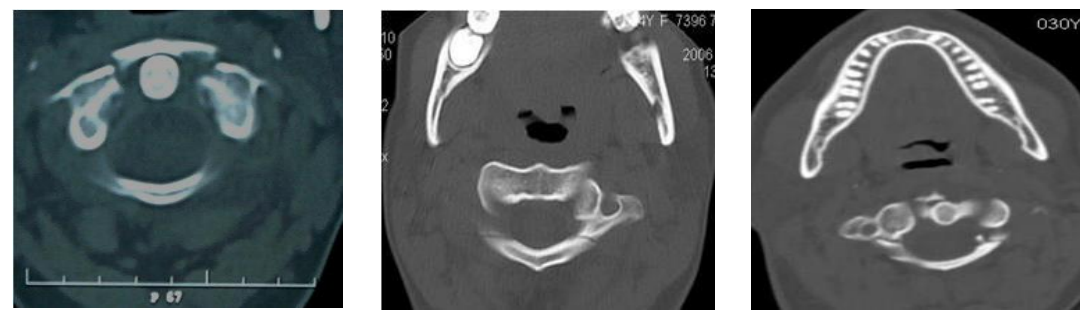

Fig. 5: Axial CT Slices of the CVJ showing the disruption of the C1 ring

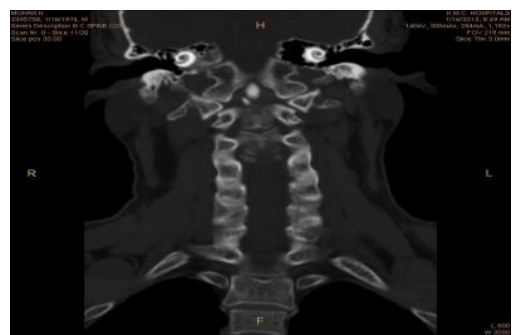

Fig. 6: Coronal CT images of the Cerivical Spine showing the overhang of the $\mathrm{C} 1$ lateral masses over the $\mathrm{C} 2$ body

MRI: is the modality most sensitive at detecting injury to transverse ligament as well as to look for damage to the cord and vascular structures.

\section{Management}

$96 \%$ of $\mathrm{C} 1$ fractures are treated with external orthroses and do not require surgery
1. Semirigid orthosis (SOMI / Philadelphia collar) are used for non displaced/minimally displaced fractures

2. Rigid External orthrosis (Halo) is used for communited lateral mass fractures and widely displaced fractures, without TAL rupture

3. Transverse ligament damage is always managed surgically owing to the resultant instability. The procedure of choice would be a transarticular screws Fixation or C1-2 lat. mass fusion when possible. Rarely if the $\mathrm{C} 1$ is completely destroyed or abnormal, an Occipito-Cervical Fusion maybe required.

\section{Conservative Non-Operative Management}

In the late 1950s, the concept of the "halo vest" was first described. This technique is based on the attachment of the halo to a device worn around the patient's torso, rather than equipment attached to a hospital bed, to provide the needed force to immobilize the cervical spine, yet allow movement.

Table 3: List of the various conservative treatment options for $\mathrm{C} 1$ fractures

\begin{tabular}{|l|l|}
\hline Fracture Type & Management Strategy \\
\hline $\begin{array}{l}\text { Isolated Ring Fracture } \\
\text {-Anterior arch } \\
\text {-Posterior arch } \\
\text {-Unilateral ring }\end{array}$ & Philadelphia collar or SOMI brace \\
\hline $\begin{array}{l}\text { Classic Jefferson Burst Fracture } \\
\text {-Minimal displacement } \\
\text {-Wide displacement }\end{array}$ & Halo brace \\
\hline $\begin{array}{l}\text { Lateral mass fracture } \\
\text {-Lateral fracture } \\
\text {-Comminuted fracture }\end{array}$ & $\begin{array}{l}\text {-Philadelphia Collar or SOMI brace } \\
\text { Transverse Ligament Rupture }\end{array}$ \\
$\begin{array}{l}\text { Surgery } \\
\text {-Transarticular screw placement } \\
\text {-C1C2 Goel fusion } \\
\text {-Occipito-Cervical Fusion } \\
\text {-C1 arch Reconstruction }\end{array}$ \\
\hline
\end{tabular}




\section{Complications include}

1. Pin loosening is by far the most common of the potential complications. This happens in about $60 \%$ of patients over the three-month course. ${ }^{9}$

2. Infection at the pin sites is another potential complication that is much less common, occurring in only $10-20 \%$ of patients. ${ }^{9}$

3. Risk of persisting instability due to insufficient healing of the TAL. ${ }^{9}$

\section{Operative Management}

Indications for surgery in Jefferson Fractures:

1. Transverse Ligament Disruption

2. Associated injuries such as AAD, Hangman's fractures or Odontoid fractures ${ }^{9}$

Complex C1 C2 fractures require special care. The following algorithm maybe used to manage these complex conditions. The preferred type of surgery, depends upon the complication present as well as the presence or absence of transverse ligament rupture. ${ }^{10}$

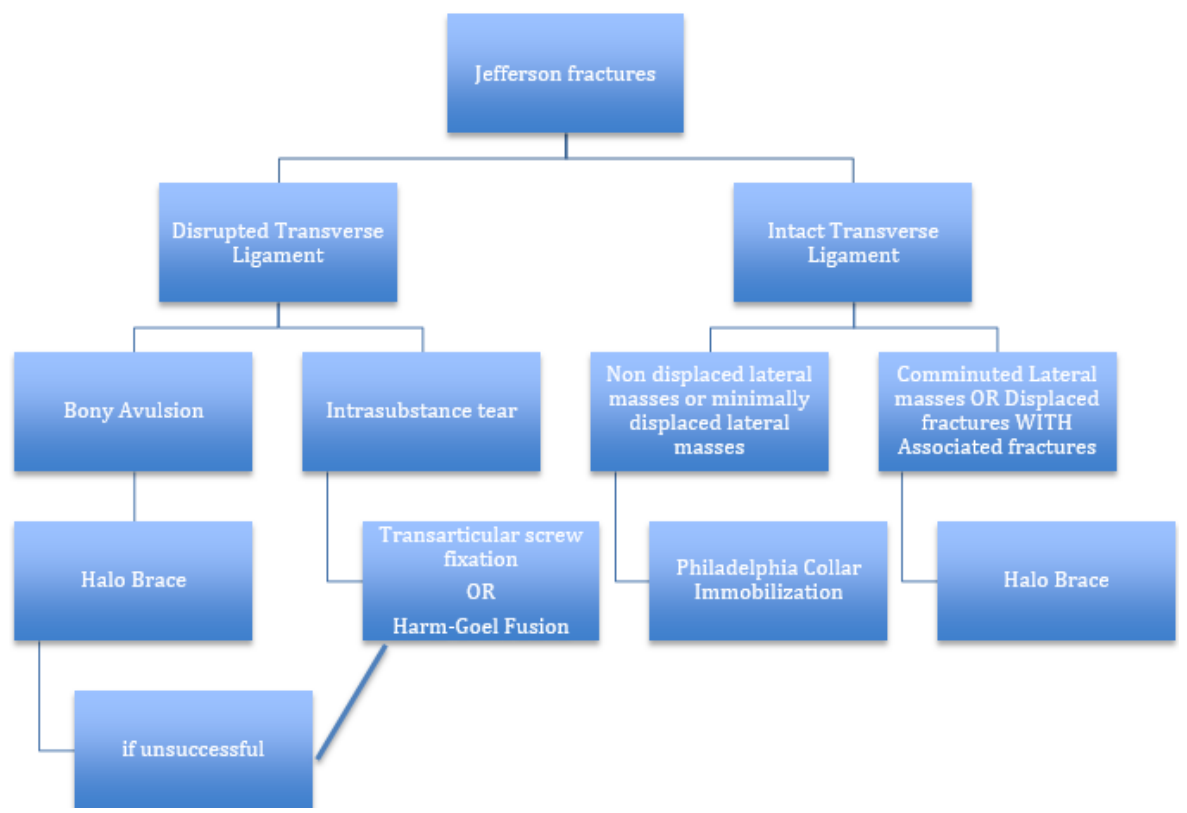

Fig. 7: Demonstrates an algorhythmn for management of $\mathrm{C} 1$ fractures with or without the disruption of the transverse ligament

\section{C1 arch reconstruction surgery}

Although Complex Jefferson fractures and unstable Jefferson fractures require surgical fusion, it results in debilitating loss of movement at the crucial $\mathrm{C} 1 \mathrm{C} 2$ joint. This has led many to consider motion-preserving options in surgery, thereby maintaining stability yet preserving a degree of movement at the CVJ. This has led to the discovery of $\mathrm{C} 1$ osteosynthesis. Here $\mathrm{C} 1$ lateral mass screws are placed and connected to each other by a rod, thereby reconstructing the ring of the atlas. The approach maybe anterior or posterior depending upon the nature of the fragments, associated odontoid fractures as well as deficits present. ${ }^{11}$ The anterior approach is often not preferred due to the morbidity associated with transoral dissection, risk of meningitis and CSF leak and risk Fig. 8[b]s of dysphagia and odynophagia. This Procedure permits movement as well as reduces the splaying of the lateral masses (due to TAL damage), thereby bringing stability to an unstable fracture. ${ }^{11}$

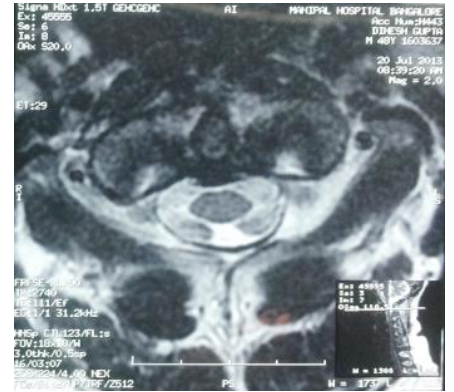

a

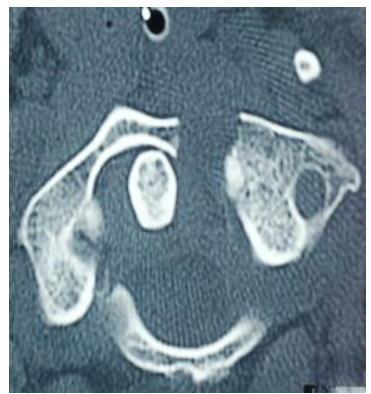

b

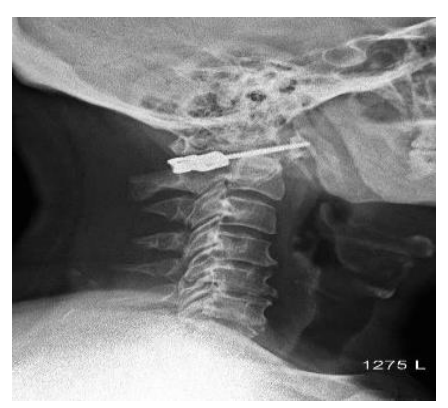

c 
Fig. 8: CT and MRI images of a patient with a pure Jefferson Fracture selected for a $\mathrm{C} 1$ arch reconstruction procedure

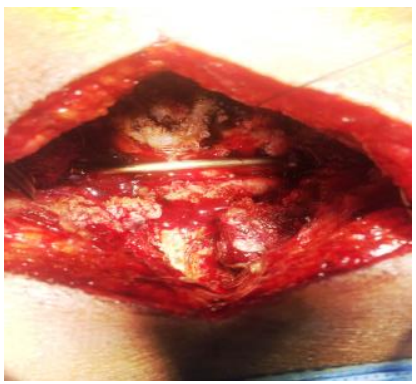

a

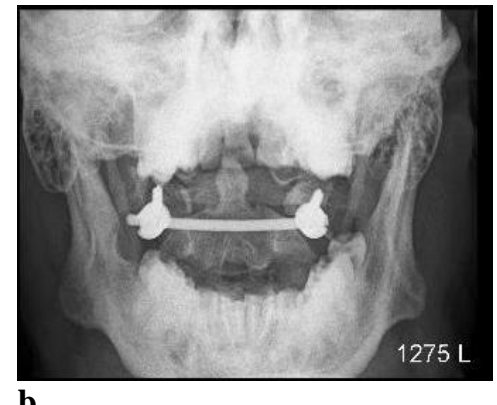

b

Fig. 9: Intra-Op and Post-Op images of the patient post $\mathrm{C}$ arch reconstruction

The compendium of studies show a gross correlation between different centres viz-a viz the different levels of recommendations for conservative and operative management. ${ }^{[11]}$ Distraction is preferred if the fragments are found inside the canal while compression of the lateral masses is preferred in classical Jefferson fracture where the canal is decompressed post injury. ${ }^{12}$

\section{Pearls:}

1. Pure Jefferson fractures are decompressive injuries.

2. They do not result in instability or neurological deficits.

3. Jefferson fractures are best diagnosed by X-ray (open mouth view) and CT Cervical spine.

4. Almost $50 \%$ of Jefferson fractures are usually seen with other CV Junction injuries.

5. $96 \%$ of Jefferson fractures do not require surgery, Rigid orthoses are sufficient.

6. C1 fractures with a reputed TAL and associated fractures require surgery.

\section{Conclusion}

Jefferson fractures are an often-overlooked aspect of cranio-vertebral junction trauma. Most do not require surgical intervention and a large majority are devoid of neurological compression. A good knowledge of anatomy and biomechanics helps in the management of this affliction.

\section{References}

1. Levine AM, Edwards CC. Fractures of the atlas. J Bone
Joint Surg Am 1991;73(5):680-91.

2. Jefferson G. Fractures of the atlas vertebra: report of four cases and a review of those previously reported. $\mathrm{Br} \mathrm{J}$ Surg 1920;7:407-22.

3. Fielding JW, Cochran GB, Lawsing JF 3rd, Hohl M. Tears of the transverse ligament of the atlas: a clinical and biomechanical study. J Bone Joint Surg Am 1974;56(8):1683-91.

4. Spence KF Jr, Decker S, Sell KW. Bursting atlantal fracture associated with rupture of the transverse ligament. J Bone Joint Surg Am 1970;52(3):543-49.

5. Heller JG, Viroslav S, Hudson T. Jefferson fractures: the role of magnification artifact in assessing transverse ligament integrity. J Spinal Disord 1993;6(5):392-96.

6. Dickman CA, Greene KA, Sonntag VK. Injuries involving the transverse atlantal ligament: classification and treatment guidelines based upon experience with 39 injuries. Neurosurg 1996;38(1):44-50.

7. Dickman CA, Sonntag VK. Injuries involving the transverse atlantal ligament: classification and treatment guidelines based upon experience with 39 injuries. Neurosurg 1997;40(4):886-87.

8. Greene KA, Dickman CA, Marciano FF, Drabier J, Drayer BP, Sonntag VK. Transverse atlantal ligament disruption associated with odontoid fractures. Spine (Phila Pa 1976). 1994;19(20):2307-14.

9. FowlerJL, SandhuA, FraserRD. Are view of fractures of the atlas vertebra. J Spinal Disord 1990;3(1):19-24.

10. Lee TT, Green BA, Petrin DR. Treatment of stable burst fracture of the atlas (Jefferson fracture) with rigid cervical collar. Spine (Phila Pa 1976). 1998;23(18):1963-67.

11. Kesterson L, Benzel E, Orrison W, Coleman J. Evaluation and treatment of atlas burst fractures (Jefferson fractures). J Neurosurg 1991;75(2):213-20.

12. Landells CD, Van Peteghem PK. Fractures of the atlas: classification, treatment and morbidity. Spine (Phila Pa 1976). $1988 ; 13(5): 450-52$. 